\title{
Mechanisms of oxidative stress, apoptosis, and autophagy involved in graphene oxide nanomaterial anti-osteosarcoma effect
}

This article was published in the following Dove Press journal:

International Journal of Nanomedicine

\author{
Zhibing Tang',2,* \\ Lin Zhao ${ }^{1,3, *}$ \\ Zaixing Yang ${ }^{3}$ \\ Zhaohui $\mathrm{Liu}^{4}$ \\ Jia $\mathrm{Gu}^{3}$ \\ Bing $\mathrm{Bai}^{3}$ \\ Jinlian Liu $^{2}$ \\ Jiaying $X u^{3}$ \\ Huilin Yang ${ }^{\prime}$ \\ 'Department of Orthopedics, The \\ First Affiliated Hospital of Soochow \\ University, Soochow University, \\ Suzhou, China; ${ }^{2}$ Department of \\ Orthopaedic Surgery, Suzhou \\ Kowloon Hospital, Shanghai Jiaotong \\ University School of Medicine, Suzhou, \\ China; ${ }^{3}$ Institute of Quantitative \\ Biology and Medicine, SRMP and \\ RAD-X, Collaborative Innovation \\ Center of Radiation Medicine of \\ Jiangsu Higher Education Institutions, \\ Soochow University, Suzhou, China; \\ ${ }^{4}$ Department of Anatomy and \\ Histology and Embryology, Basic \\ Medical and Biological Sciences, \\ School of Medicine, Soochow \\ University, Suzhou, China \\ *These authors contributed equally \\ to this work
}

Correspondence: Huilin Yang; Jiaying Xu No. 899 Pinghai Road, Department of Orthopedics, The First Affiliated Hospital of Soochow University, Suzhou 215006, China

Tel +86 05 I26 5223637

Email suzhoutrauma@।26.com; xujiaying@suda.edu.cn
Background: Graphene and its derivative graphene oxide (GO) have been implicated in a wide range of anticancer effects.

Purpose: The objective of this study was to systematically evaluate the toxicity and underlying mechanisms of GO on two osteosarcoma (OSA) cancer cell lines, MG-63 and $\mathrm{K}_{7} \mathrm{M}_{2}$ cells.

Methods: MG-63 and $\mathrm{K}_{7} \mathrm{M}_{2}$ cells were treated by GO $(0-50 \mu \mathrm{g} / \mathrm{mL})$ for various time periods. Cell viability was tested by MTT and Live/Dead assays. A ROS Detection Kit based on DHE oxidative reaction was used for ROS detection. An Annexin V-FITC Apoptosis Kit was used for apoptosis detection. Dansylcadaverine (MDC) dyeing was applied for seeking unspecific autophagosomes. Western blot and Immunofluorescence analysis were used for related protein expression and location.

Results: $\mathrm{K}_{7} \mathrm{M}_{2}$ cells were more sensitive to $\mathrm{GO}$ compared with MG- 63 cells. The mechanism was attributed to the different extent of the generation of reactive oxygen species (ROS). In $\mathrm{K}_{7} \mathrm{M}_{2}$ cells, ROS was easily stimulated and the apoptosis pathway was subsequently activated, accompanied by elevated expression of proapoptosis proteins (such as caspase-3) and decreased expression levels of antiapoptosis proteins (such as Bcl-2). A ROS inhibitor ( $N$-acetylcysteine) could alleviate the cytotoxic effects of GO in $\mathrm{K}_{7} \mathrm{M}_{2}$ cells. However, the production of ROS in MG-63 cells was probably inhibited by the activation of an antioxidative factor, nuclear factor-E2-related factor-2, which translocated from the cytoplasm to the nucleus after GO treatment, while a nuclear factorE2-related factor-2 inhibitor (ML385) significantly increased ROS production in MG-63 cells when combined with GO treatment. In addition, autophagy was simultaneously stimulated by characteristic autophagosome formation, autophagy flux, and increased the expression level of autophagy-related proteins (such as LC3I to LC3II conversion, ATG5, and ATG7).

Conclusion: This paper proposes various underlying mechanisms of the anticancer effect of GO. The novel synthetic use of GO with an oxidizing agent is the key step for further potential applications in clinical OSA cancer therapy.

Keywords: graphene oxide, osteosarcoma cancer, ROS, apoptosis, autophagy

\section{Introduction}

Osteosarcoma (OSA) is one of the most common malignant tumors that easily occur predominantly in children, adolescents, and young adults. ${ }^{1}$ Although its incidence is lower than that of other malignant tumors, its characteristics, including high mortality rate, early distant metastasis, and confusion with trauma, make OSA a challenge for clinical diagnosis and therapy. ${ }^{2}$ In practice, the combination of aggressive surgical resection, chemotherapy, and radiotherapy offers a certain extent of improvement for OSA patients. However, the rapid proliferation rate and the invasive potential of 
OSA cancer cells remain the major cause of death. ${ }^{3}$ Thus, development of new agents is urgently needed for clinical OSA therapy.

Recently, nanomaterials have been widely studied for biomedical applications due to their congruent combination of chemical, physical, and biologic properties. Given the carbon-based chemistry and outstanding biocompatible properties, graphene oxide (GO) has attracted considerable interest among nanomaterials such as silver, zinc oxide, and magnesium oxide. ${ }^{4} \mathrm{GO}$ has been explored in a wide range of diagnostic and therapeutic fields, showing potential in areas such as engineered tissues, ${ }^{5}$ drug delivery carriers, ${ }^{6}$ biomedical imaging, ${ }^{7}$ antibacterial materials, ${ }^{8}$ Alzheimer's disease diagnosis, ${ }^{9}$ and anticancer ${ }^{10}$ therapies.

The underlying mechanisms of GO or characterized GO anticancer effects were extensively studied previously. The toxic effect of GO was primarily attributed to the generation of reactive oxygen species (ROS). For example, GO can induce cytotoxicity against human breast cancer MDAMB-231 cells probably due to cellular ROS generation. ${ }^{11}$ Increased ROS, lactate dehydrogenase release, activation of caspase-3, and DNA fragmentation were also claimed to be involved in acid-reduced, GO-induced anti-human ovarian cancer effects. ${ }^{12}$ In addition, GO nanosheets exert significant toxicity to human liver cancer $\mathrm{HepG}_{2}$ cells, which is related to the activation of intrinsic apoptotic caspase-independent pathway and S phase cell cycle arrest. ${ }^{13}$ Notably, autophagy maintains cellular homeostasis by clearing damaged protein or organelles as a recycling process, but excessive autophagy is closely related to the induction of autophagic cell death. ${ }^{14}$ Reportedly, increased ROS production and autophagy are simultaneously induced by GO at low concentrations in neuroblastoma cell lines without cell growth arrest or death. ${ }^{15}$ Thus, the underlying mechanisms accompanied by ROS remain controversial in GO-induced anticancer effects, which have not been well investigated.

In this study, we aim to evaluate the cytotoxic effects of GO on human OSA MG-63 cells and murine OSA $\mathrm{K}_{7} \mathrm{M}_{2}$ cells and explore the mechanisms related to the cell death pathways stimulated by GO.

\section{Materials and methods}

\section{Materials}

GO (50-200 nm) was purchased from Chengdu Organic Chemical Co., Chinese Academy of Sciences (Chengdu, China). MTT, 4,6-diamidino-2-phenyl-indole, dihydroethidium (DHE), $N$-acetylcysteine (NAC), and Bafilomycin A1 (Baf) were supplied by Sigma-Aldrich Co. (St Louis, MO, USA). Nuclear factor-E2-related factor-2 (Nrf-2) inhibitor (ML385) was bought from MedChem Express Co. (Shanghai, China). The Live/Dead viability kit was purchased from Thermo Fisher Scientific (Waltham, MA, USA). The antibodies including Nrf-2, ATG3, ATG5, ATG7, caspase-3, cleaved-caspase-3, and lamin B1 were provided by Cell Signaling Technology (Beverly, MA, USA). Antibodies of LC3, Bcl-2, and $\beta$-actin were provided by Santa Cruz Biotechnology Inc. (Santa Cruz, CA, USA).

\section{Cell cultures}

MG-63 and $\mathrm{K}_{7} \mathrm{M}_{2}$ cells were obtained from the American Type Culture Collection (ATCC, Rockville, MD, USA). They were maintained in DMEM (Thermo Fisher Scientific) with $10 \%$ fetal calf serum. Nonessential amino acids ( $5 \mathrm{mmol} / \mathrm{L})$, L-glutamine $(5 \mathrm{mmol} / \mathrm{L})$, penicillin $(100 \mathrm{U} / \mathrm{mL})$, and streptomycin (100 U/mL; Thermo Fisher Scientific) were added to the culture medium, and the cells were kept in a humidified $5 \% \mathrm{CO}_{2}$ atmosphere at $37^{\circ} \mathrm{C}$.

\section{Cell viability assay}

MTT assay was used for cell viability. Briefly, 6,000 cells/well (MG-63 and $\mathrm{K}_{7} \mathrm{M}_{2}$ cells) were seeded into 96-well cell culture plates. They were treated with GO of different concentrations $(0-50 \mu \mathrm{g} / \mathrm{mL})$ for $0.5,2,4,6$, and $8 \mathrm{~h}$. Besides, for evaluation of NAC's (a ROS scavenger) influence on GO's cytotoxic effect, MG-63 and $\mathrm{K}_{7} \mathrm{M}_{2}$ cells were also treated with GO with or without NAC $(10 \mathrm{mmol} / \mathrm{L})$ and then incubated for the next $8 \mathrm{~h}$. Then, $20 \mu \mathrm{L}$ MTT and $150 \mu \mathrm{L}$ dimethyl sulfoxide were added for the MTT assay as previously described. ${ }^{16}$

\section{Observation of morphology}

MG-63 and $\mathrm{K}_{7} \mathrm{M}_{2}$ cells were incubated in 0,25 , and $50 \mu \mathrm{g} / \mathrm{mL}$ GO for 2, 4, and $8 \mathrm{~h}$. Subsequently, the cells were observed after washing with PBS by using an ordinary digital camera (Olympus, Tokyo, Japan).

\section{Live/Dead assay}

At the same time, cell viability was also tested using a Live/ Dead assay. MG-63 and $\mathrm{K}_{7} \mathrm{M}_{2}$ cells were incubated in the absence or presence of 25 and $50 \mu \mathrm{g} / \mathrm{mL}$ GO for 2,4 , and $8 \mathrm{~h}$. Briefly, $1 \mathrm{~mL}$ of PBS containing $4 \mu \mathrm{L}$ of $2 \mathrm{mM}$ ethidium homodimer-1 (EthD-1) assay solution and $2 \mu \mathrm{L}$ of $50 \mu \mathrm{M}$ calcein AM assay solution was prepared. Then, $200 \mu \mathrm{L}$ of the Live/Dead solution was added to each well for $15 \mathrm{~min}$ in an incubator at $37^{\circ} \mathrm{C}$. The staining solution was removed and the samples were then imaged under a fluorescence microscope (Olympics IX73) with $494 \mathrm{~nm}$ (green, calcein) and $528 \mathrm{~nm}$ (red, EthD-1) excitation filters. 


\section{Intracellular ROS assay}

A ROS Detection Kit (Sigma Co., St Louis, MO, USA) was used for ROS detection, based on DHE oxidative reaction. MG-63 and $\mathrm{K}_{7} \mathrm{M}_{2}$ cells were treated in the absence or presence of 25 and $50 \mu \mathrm{g} / \mathrm{mL}$ GO for $0.5,2,4$, and $8 \mathrm{~h}$. To explore Nrf-2's effect on ROS generation, MG-63 cells were also incubated with GO (25 and $50 \mu \mathrm{g} / \mathrm{mL}$ ) with or without Nrf-2 inhibitor (ML385, 2 $\mu \mathrm{M})$ for 2 and $4 \mathrm{~h}$. Then, $5 \mu \mathrm{M}$ DHE assay reagent was added and the cells were incubated at $37^{\circ} \mathrm{C}$ for $30 \mathrm{~min}$. Finally, the cells were washed and maintained in PBS. Their images were captured using a fluorescence microscope (Carl Zeiss Microimaging, NY, USA), and the fluorescence intensity was determined by FACS Calibur (Becton Dickinson, San Jose, CA, USA).

\section{Detection of cell apoptosis}

An Annexin V-FITC Apoptosis Kit (BD Biosciences, CA, USA) was used for apoptosis detection according to the manufacturer's instructions. At 4 and $8 \mathrm{~h}$ after incubation with 25 and $50 \mu \mathrm{g} / \mathrm{mL} \mathrm{GO}, \mathrm{K}_{7} \mathrm{M}_{2}$ cells were harvested and washed with PBS. Apoptosis of cells was tested and analyzed as previously described. ${ }^{16}$

\section{Visualization of autophagosomes}

Dansylcadaverine (MDC) dyeing method was also applied to seek unspecific autophagosomes. MG-63 and $\mathrm{K}_{7} \mathrm{M}_{2}$ cells were treated with 0,25 , and $50 \mu \mathrm{g} / \mathrm{mL}$ GO for $2 \mathrm{~h}$, respectively. Afterwards, the cells were washed with PBS and dyed with MDC working solution $(50 \mu \mathrm{M})$ for $30 \mathrm{~min}$ at room temperature. The images were captured by a fluorescence microscope.

\section{Western blot}

MG-63 and $\mathrm{K}_{7} \mathrm{M}_{2}$ cells were incubated with or without 25 and $50 \mu \mathrm{g} / \mathrm{mL}$ GO for 2, 4, and $8 \mathrm{~h}$. For the combined treatment with $50 \mu \mathrm{g} / \mathrm{mL}$ GO and autophagy inhibitor (Baf, $100 \mathrm{nmol} / \mathrm{L}$ ), Baf was added $4 \mathrm{~h}$ before the cells were harvested. Cellular total protein, cytoplasmic and nuclear proteins were extracted as previously described. ${ }^{16}$ Notably, NE-PER Nuclear and Cytoplasmic Extraction Reagent Kit (Thermo Fisher Scientific) was used for the isolation of cytoplasmic and nuclear proteins. The blots were carried out as previously reported. ${ }^{16}$ The antibodies of $\beta$-actin, Nrf-2, caspase-3, cleaved-caspase-3, Bcl-2, ATG5, ATG3, ATG7, and LC3 proteins were diluted at a concentration 1:1,000 with $5 \%$ fresh non-fat milk.

\section{Immunofluorescence analysis}

MG-63 and $\mathrm{K}_{7} \mathrm{M}_{2}$ cells were plated onto circular glass coverslips and were stimulated with GO $(25 \mu \mathrm{g} / \mathrm{mL})$ for $2 \mathrm{~h}$.
Subsequently, the cells were fixed and permeabilized with $2 \%$ formalin and $0.1 \%$ Triton X-100 (10 min, room temperature). Nrf-2 primary antibody $(1: 100)$ and a rabbit IgG-CY3 secondary antibody (1:500) were added and incubated overnight at $4^{\circ} \mathrm{C}$. The nucleus was stained with $5 \mu \mathrm{g} / \mathrm{mL} 4,6-$ diamidino-2-phenyl-indole (30 min, room temperature).

\section{Statistical analysis}

Data are expressed as mean \pm SD for at least two to three independent experiments. Two-tailed Student's $t$-test was used for making comparisons between the treated group and the control group. All statistical tests used SPSS version 17.0. $P$-value of 0.05 or less between the groups was considered significant.

\section{Results GO inhibits the growth of MG-63 and $\mathrm{K}_{7} \mathrm{M}_{2}$ cells}

The cytotoxic effects of $\mathrm{GO}$ on $\mathrm{MG}-63$ and $\mathrm{K}_{7} \mathrm{M}_{2}$ cells were tested by MTT assay. After GO treatment at $0-50 \mu \mathrm{g} / \mathrm{mL}$ (without fetal bovine serum [FBS]), the viabilities of both MG-63 and $\mathrm{K}_{7} \mathrm{M}_{2}$ cells were decreased in a dose- and timedependent manner (Figure 1A and B). In general, $\mathrm{K}_{7} \mathrm{M}_{2}$ cells are more sensitive to GO compared with MG-63 cells. For example, the survival rate of $\mathrm{K}_{7} \mathrm{M}_{2}$ cells was $54.23 \% \pm 3.97 \%$ after treatment with $50 \mu \mathrm{g} / \mathrm{mL}$ GO for $6 \mathrm{~h}$, whereas the survival rate of MG-63 cells was $72.04 \% \pm 4.22 \%$.

To further quantify the survival rates of GO-treated OSA cells, we applied fluorescence probes to track live and dead cells in solution. EthD-1 enters the damaged/dead cells and produces a bright-red fluorescence signal, whereas calcein AM is retained by live cells and produces green light. In Figure 2A, decreased green light intensities are observed in $\mathrm{GO}$ ( 25 and 50 $\mu \mathrm{g} / \mathrm{mL}$ )-treated MG-63 cells compared with the untreated control and the gap between cells has become widened. However, marked changes were not detected in red light intensities, indicating that $\mathrm{GO}$ induces inhibition of cell proliferation instead of cell death at the given concentrations. By contrast, the number of cells emitting green light diminished in GO-treated $\mathrm{K}_{7} \mathrm{M}_{2}$ cells, whereas the number of cells emitting red light increased, confirming strong cytotoxic effects (Figure 2B).

\section{GO induces morphologic changes in MG-63 and $\mathrm{K}_{7} \mathrm{M}_{2}$ cells}

For further detecting the effect of GO on the morphologic changes in OSA cells, the MG- 63 and $\mathrm{K}_{7} \mathrm{M}_{2}$ cells were examined through a microscope after they were exposed to GO nanomaterials and incubated in 25 and $50 \mu \mathrm{g} / \mathrm{mL} \mathrm{GO}$ solutions without FBS for 2,4 , and $8 \mathrm{~h}$. In the treated groups, aggregated 

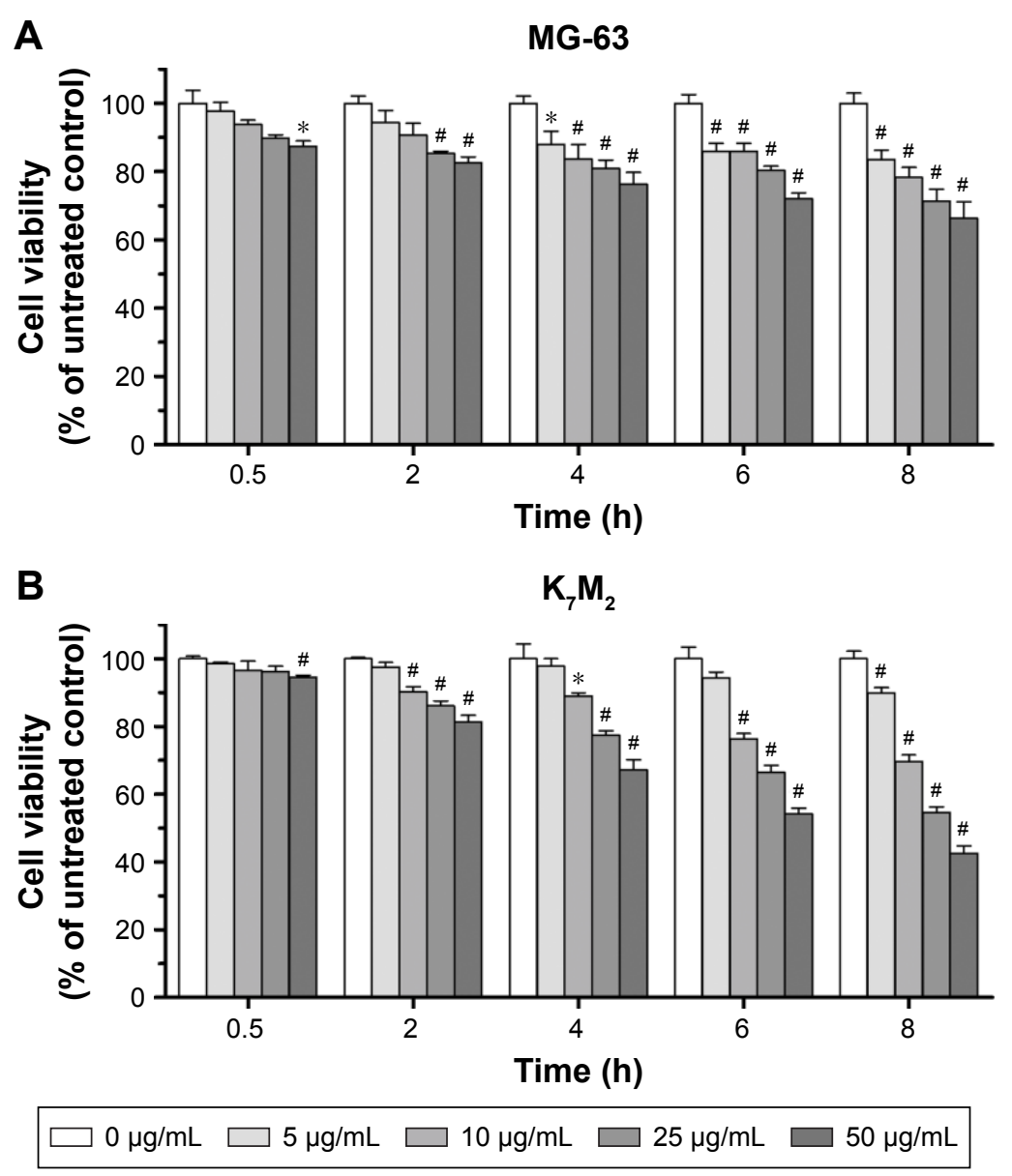

Figure I The cytotoxic effect of GO on MG-63 and $K_{7} M_{2}$ cells. (A) MG-63 and (B) $K_{7} M_{2}$ cells were exposed to varying concentrations of GO for different treatment periods (without FBS).

Notes: The effects on cell viability were determined using an MTT assay with GO $(0-50 \mu \mathrm{g} / \mathrm{mL})$ treatment for $0.5-8 \mathrm{~h}$. Cell viability was calculated as a percentage of untreated cells $(100 \%)$ and compared with untreated control. Values are presented as mean $\pm S D\left(* P<0.05,{ }^{\#} P<0.0 I\right)$.

Abbreviations: FBS, fetal bovine serum; GO, graphene oxide.

GO nanomaterials were visible and adherent on the surface of both types of cells, indicating their interaction with the cell membrane (Figure 3A and B, yellow arrows). Compared with the untreated control, MG-63 cells in the GO-treated group appeared slightly vimineous and polygonal, possibly indicating internal damage. However, $\mathrm{K}_{7} \mathrm{M}_{2}$ cells were observed to be more seriously damaged after an equivalent treatment. Most cells became inflated and riddled with large cytoplasmic vacuoles, as highlighted by the red arrows in Figure 3B. We also found that a number of cells exhibited changes in orientation. Groups of cells became disordered and only loosely adhered to their substrates; finally, numerous cells floated in isolation in the medium (indicating that such cells were dead).

\section{GO induces ROS generation in MG-63 and $\mathrm{K}_{7} \mathrm{M}_{2}$ cells}

As the product of oxidative stress reaction, ROS generated from the nanomaterials and by cell interaction were recognized as one of the most significant causes of cell damage. ${ }^{11,12}$ To further detect whether GO induced ROS generation in the two OSA cancer cells, we applied DHE dyeing method. As Figure 4A shows, 25 and $50 \mu \mathrm{g} / \mathrm{mL}$ GO treatment for $2 \mathrm{~h}$ slightly induced ROS generation in MG-63 cells, whereas similar treatments of $\mathrm{K}_{7} \mathrm{M}_{2}$ cells rapidly stimulated the fluorescent compound ethidium. For example, compared with the untreated control, treatment of $\mathrm{K}_{7} \mathrm{M}_{2}$ cells with GO (25 $\mu \mathrm{g} / \mathrm{mL}$ ) for $0.5 \mathrm{~h}$ markedly increased the ROS content 3 -fold (Figure 4B), indicating increased sensitivity of $\mathrm{K}_{7} \mathrm{M}_{2}$ cells relative to MG-63 cells.

To explore whether ROS production was one of the reasons for GO inducing cell growth inhibition in both cells, a ROS scavenger, NAC, was applied with and without GO treatment. In MG-63 cells, compared to GO treatment alone, NAC (10 mmol/L) had no obvious effect on cell growth when it was combined with 25 and $50 \mu \mathrm{g} / \mathrm{mL}$ GO treatment for $8 \mathrm{~h}(P>0.05$, Figure $4 \mathrm{C})$. In contrast, NAC $(10 \mathrm{mmol} / \mathrm{L})$ 
A
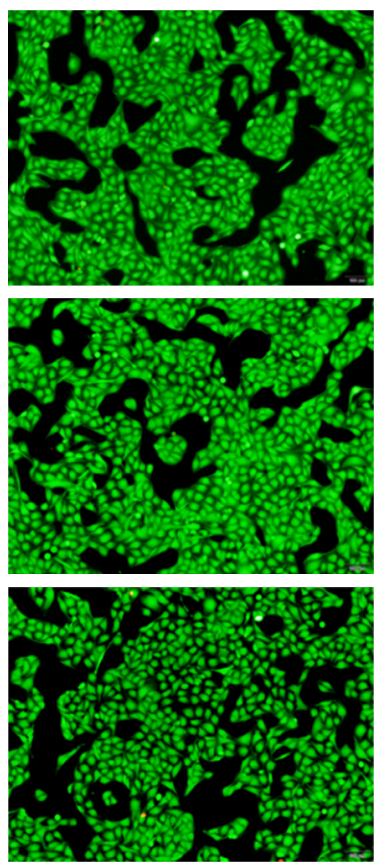

0

B
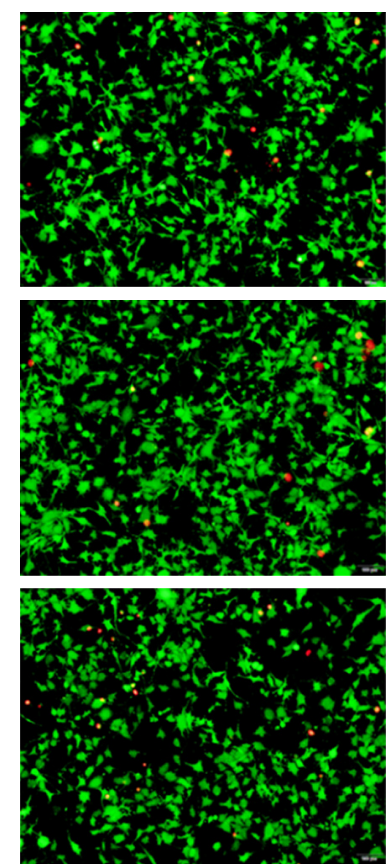

0
MG-63
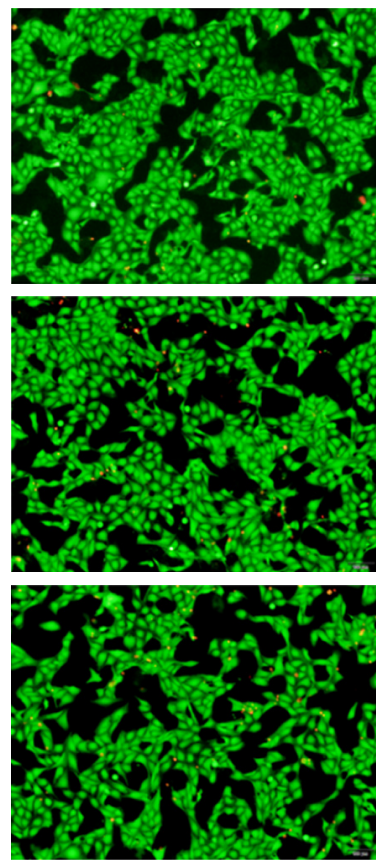

25
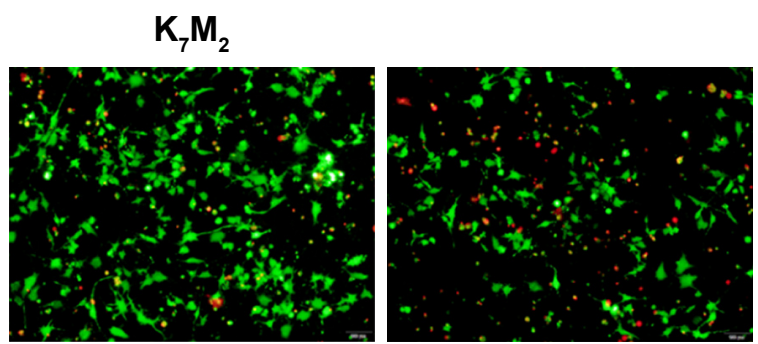

$2 \mathrm{~h}$

50
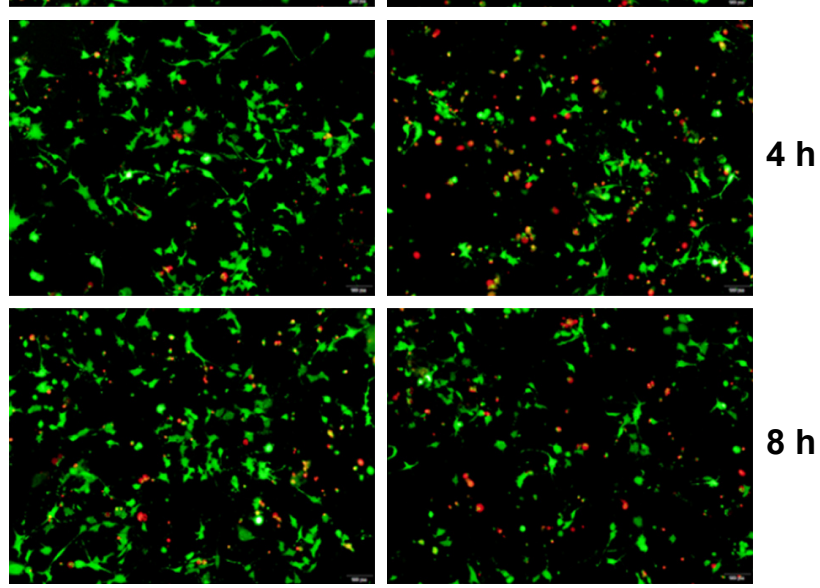

25

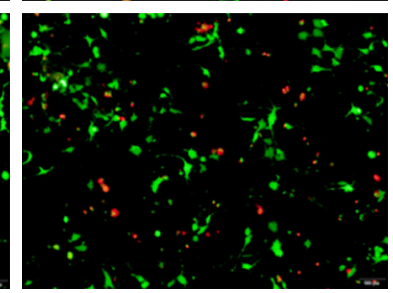

50
GO $(\mu \mathrm{g} / \mathrm{mL})$

$2 \mathrm{~h}$

$4 \mathrm{~h}$

$8 \mathrm{~h}$

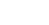

$4 \mathrm{~h}$

$8 \mathrm{~h}$

GO $(\mu \mathrm{g} / \mathrm{mL})$

Figure 2 Live/Dead assay of GO on (A) MG-63 and (B) $\mathrm{K}_{7} \mathrm{M}_{2}$ cells.

Note: A live (cells illuminated by green light)/dead (cells illuminated by red light) assay after treatment with $0,25,50 \mu \mathrm{g} / \mathrm{mL} \mathrm{GO}$ (without FBS) for 2,4 , and $8 \mathrm{~h}$.

Abbreviations: FBS, fetal bovine serum; GO, graphene oxide.

significantly increased the cell viability from $52.89 \% \pm 5.34 \%$ (25 $\mu \mathrm{g} / \mathrm{mL}$ GO) to $81.07 \% \pm 4.83 \%$ ( $25 \mu \mathrm{g} / \mathrm{mL}$ GO with NAC; $\left.{ }^{*} P<0.01\right)$, and from $42.88 \% \pm 2.50 \%(50 \mu \mathrm{g} / \mathrm{mL}$ GO) to $68.83 \% \pm 2.97 \%$ (50 $\mu \mathrm{g} / \mathrm{mL}$ GO with NAC; $\left.{ }^{\#} P<0.01\right)$ in
$\mathrm{K}_{7} \mathrm{M}_{2}$ cells. All these results revealed that ROS generation was important for its great contribution to cell death in $\mathrm{K}_{7} \mathrm{M}_{2}$ cells. However, in MG-63 cells, the cell growth inhibition seemed to have no relationship with ROS production. 


\section{A}
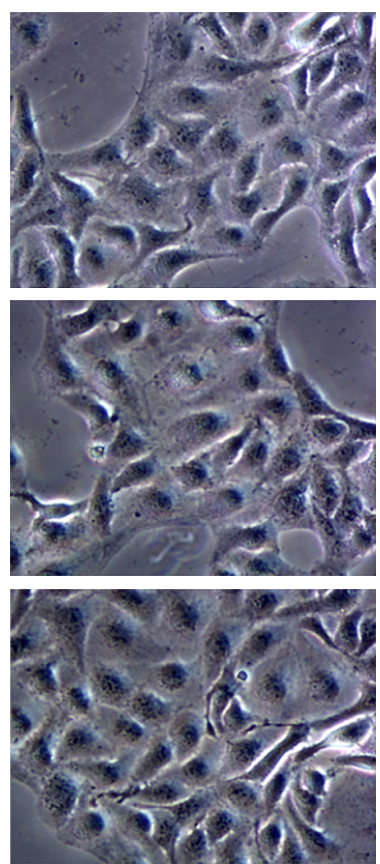

0

B

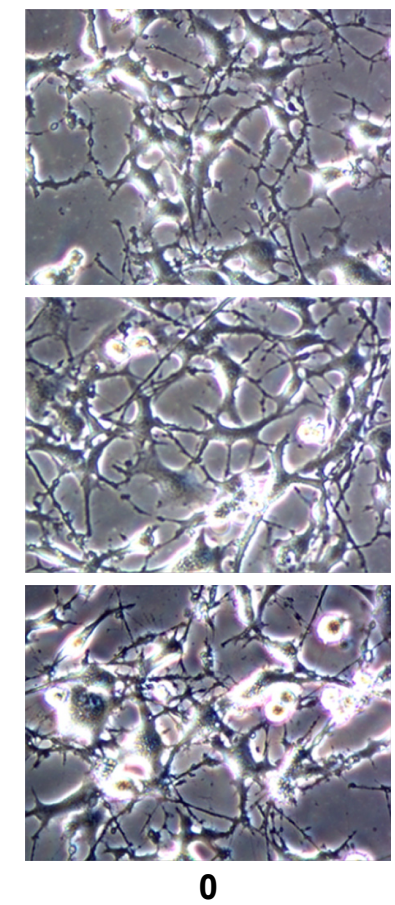

MG-63
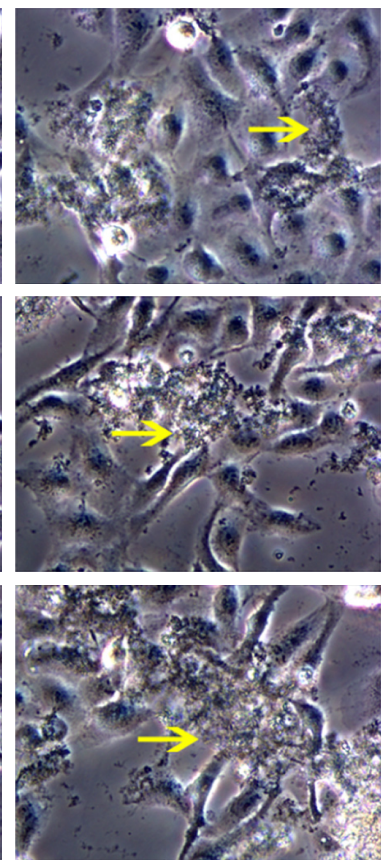

25
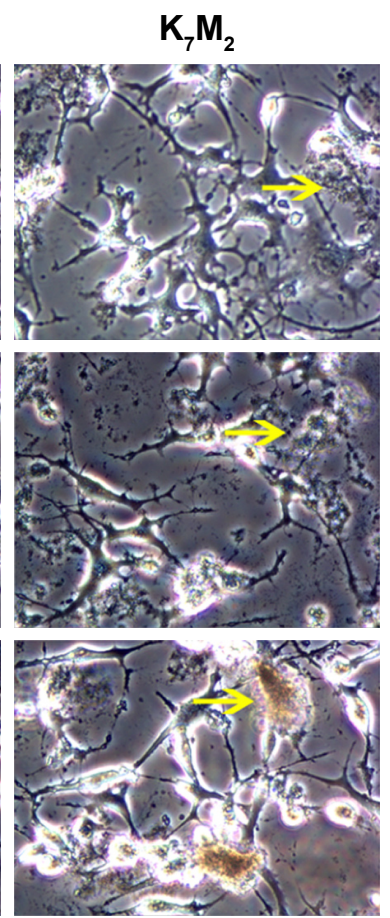

25

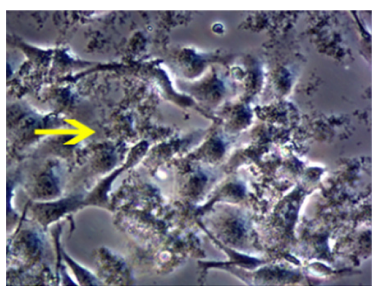

$2 \mathrm{~h}$

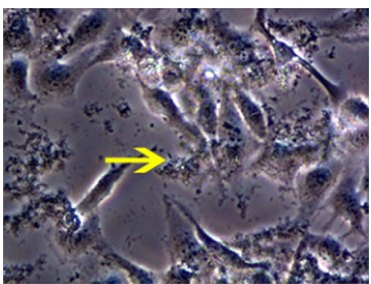

$4 \mathrm{~h}$

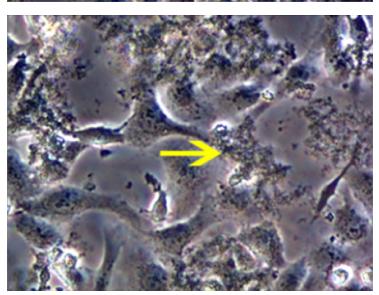

50
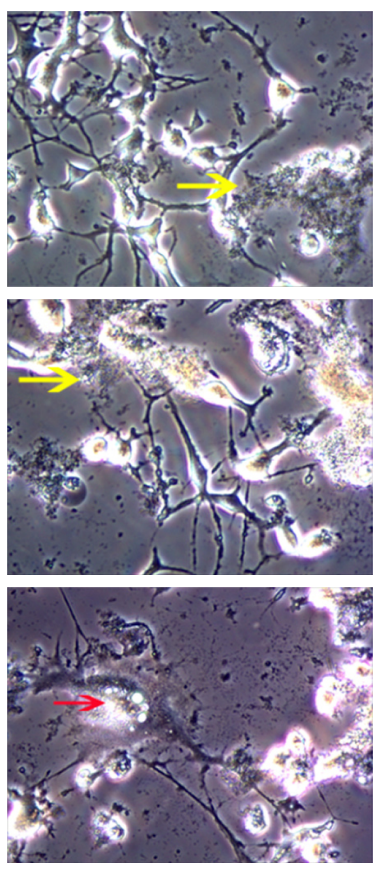

50
$2 \mathrm{~h}$

\section{GO ( $\mu \mathrm{g} / \mathrm{mL})$}

$8 \mathrm{~h}$

$4 h$

$8 \mathrm{~h}$

\section{$\mathrm{GO}(\mu \mathrm{g} / \mathrm{mL})$}

Figure 3 Morphology detection of GO in MG-63 and $K_{7} M_{2}$ cells.

Notes: (A) MG-63 and (B) $\mathrm{K}_{7} \mathrm{M}_{2}$ cells were treated with 0, 25, $50 \mu \mathrm{g} / \mathrm{mL} \mathrm{GO}$ (without FBS) for 2, 4, and 8 h. Yellow arrows: GO material. Red arrows: $\mathrm{K}_{7} \mathrm{M}_{2}$ cells with large vacuoles.

Abbreviations: FBS, fetal bovine serum; GO, graphene oxide.

GO induces Nrf-2 translocation from the cytoplasm to the nucleus in MG-63 cells

Nrf-2 was previously reported as a basic leucine zipper protein that regulates the expression of antioxidant proteins and protects against oxidative damage triggered by injury and inflammation. Given that $\mathrm{GO}$ induced ROS production in both OSA cancer cells, Nrf-2 location (Figure 5A) and expression (Figure 5B) were examined through immunofluorescence 

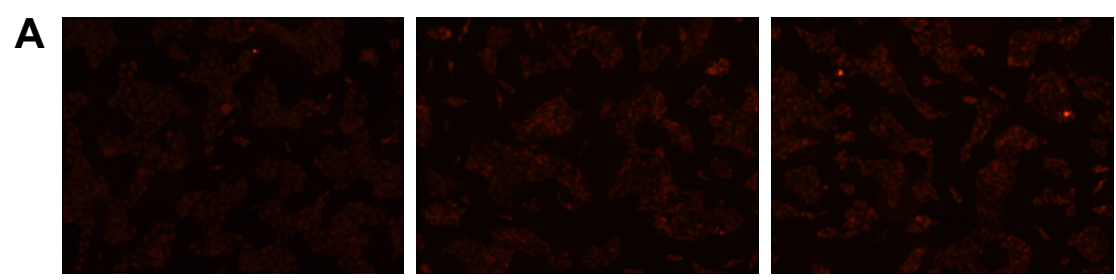

MG-63

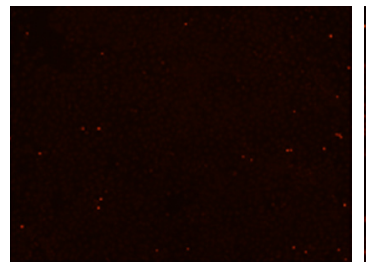

0

MG-63
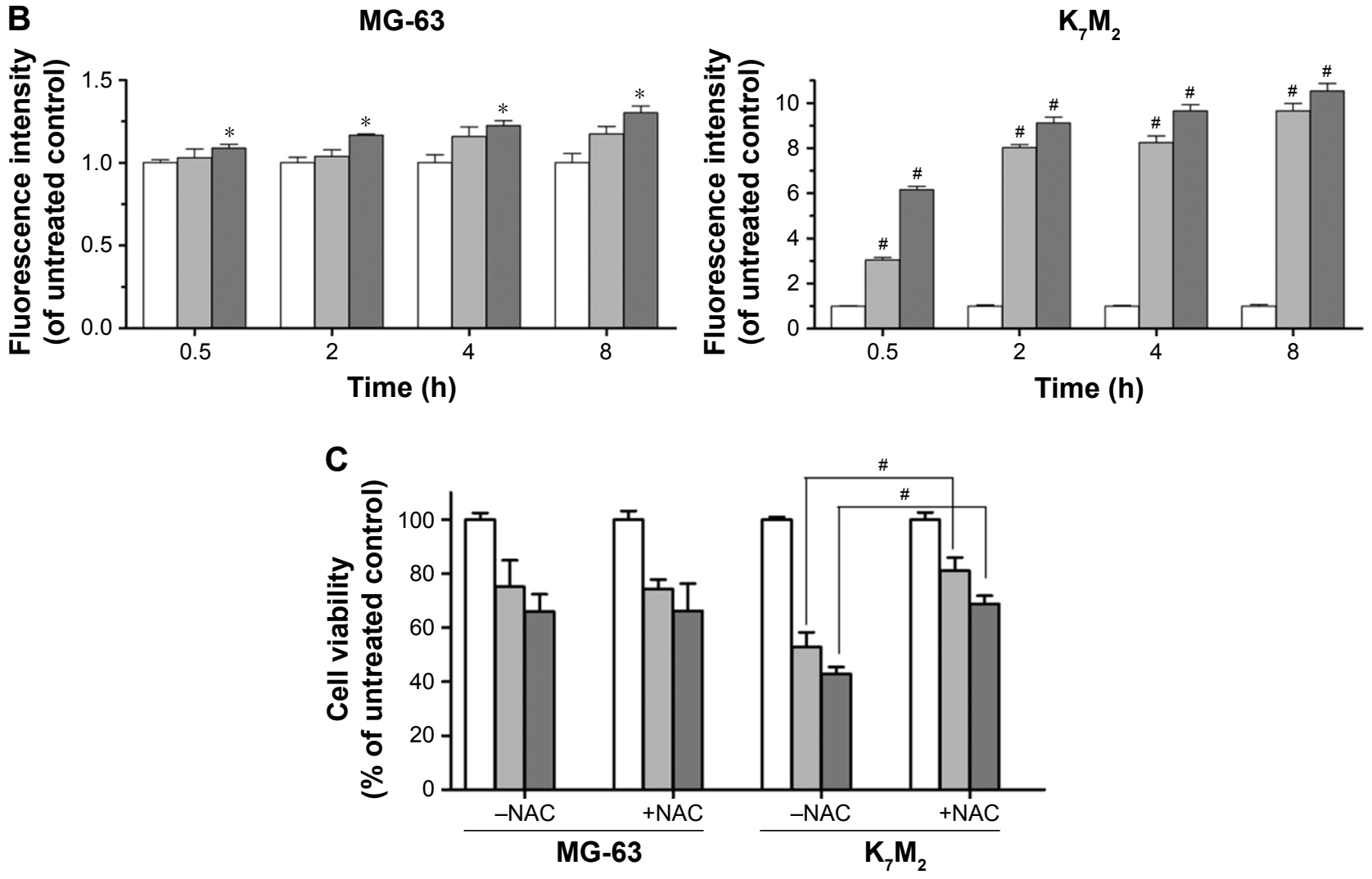

$0 \mu \mathrm{g} / \mathrm{mL} \square 25 \mu \mathrm{g} / \mathrm{mL} \square 50 \mu \mathrm{g} / \mathrm{mL}$

Figure $4 \mathrm{GO}$ induces ROS generation in MG-63 and $\mathrm{K}_{7} \mathrm{M}_{2}$ cells.

Notes: (A) MG-63 and $K_{7} M_{2}$ cells were treated with 0,25 , and $50 \mu \mathrm{g} / \mathrm{mL}$ GO for $2 \mathrm{~h}$. Then, DHE analyses were applied to detect ROS generation. (B) Fluorescence analysis of ROS content. MG- 63 and $\mathrm{K}_{7} \mathrm{M}_{2}$ cells were treated with 0,25 , and $50 \mu \mathrm{g} / \mathrm{mL} \mathrm{GO}$ for $0.5,2,4$, and 8 h. Fluorescence intensity was calculated compared to untreated control cells. Values are presented as mean \pm SD and compared with untreated control $\left({ }^{*} P<0.05\right.$, $\left.{ }^{*} P<0.0 \mathrm{I}\right)$. (C) Cell viability assay was conducted by $M T T$. MG-63 and $\mathrm{K}_{7} \mathrm{M}_{2}$ cells were treated with 0,25 , and $50 \mu \mathrm{g} / \mathrm{mL}$ GO with or without NAC (I0 mmol/L) for $8 \mathrm{~h}$. ${ }^{*} P<0.0 \mathrm{l}$ (compared with GO treatment alone).

Abbreviations: DHE, dihydroethidium; GO, graphene oxide; NAC, $\mathrm{N}$-acetylcysteine; ROS, reactive oxygen species.

and Western blot assays. On treatment with $25 \mu \mathrm{g} / \mathrm{mL}$ GO for $2 \mathrm{~h}$, the Nrf-2 cytoplasm emitting red fluorescence was transferred to MG-63 cell nucleus (Figure 5A and B). However, the location and expression of Nrf-2 in $\mathrm{K}_{7} \mathrm{M}_{2}$ cells were not markedly affected under the same condition. These findings indicated that GO induced Nrf-2 activation in MG-63 cells.
To further prove that Nrf-2 translocation and activation played an important role in diminishing ROS production in MG-63 cells, an Nrf-2 inhibitor, ML385, ${ }^{17}$ was used in the absence or presence of GO for 2 and $4 \mathrm{~h}$. As shown in Figure 5C, compared to GO treatment alone, ML385 $(2 \mu \mathrm{mol} / \mathrm{L})$ could significantly increase cellular ROS level by $\sim 2-4$-fold in MG-63 cells after co-incubation $\left({ }^{\sharp} P<0.01\right)$. 
The results indicated that Nrf-2 activation was closely connected with and negatively regulated ROS generation.

$\mathrm{GO}$ induces apoptosis in $\mathrm{K}_{7} \mathrm{M}_{2}$ cancer cells To further understand the mechanism of GO-induced $\mathrm{K}_{7} \mathrm{M}_{2}$ cell death, we determined whether apoptosis was enhanced by GO. The results showed that the application of GO for 4 and $8 \mathrm{~h}$ significantly induced viable (VA\%) and nonviable apoptosis cell (NVA\%) percentages in a dose-dependent manner (Figure 6A). GO treatment at 25 and $50 \mu \mathrm{g} / \mathrm{mL}$ for $4 \mathrm{~h}$ upregulated VA\% and NVA\% $(P<0.01)$. However, when the treatment was extended for as long as $8 \mathrm{~h}$ at the
A
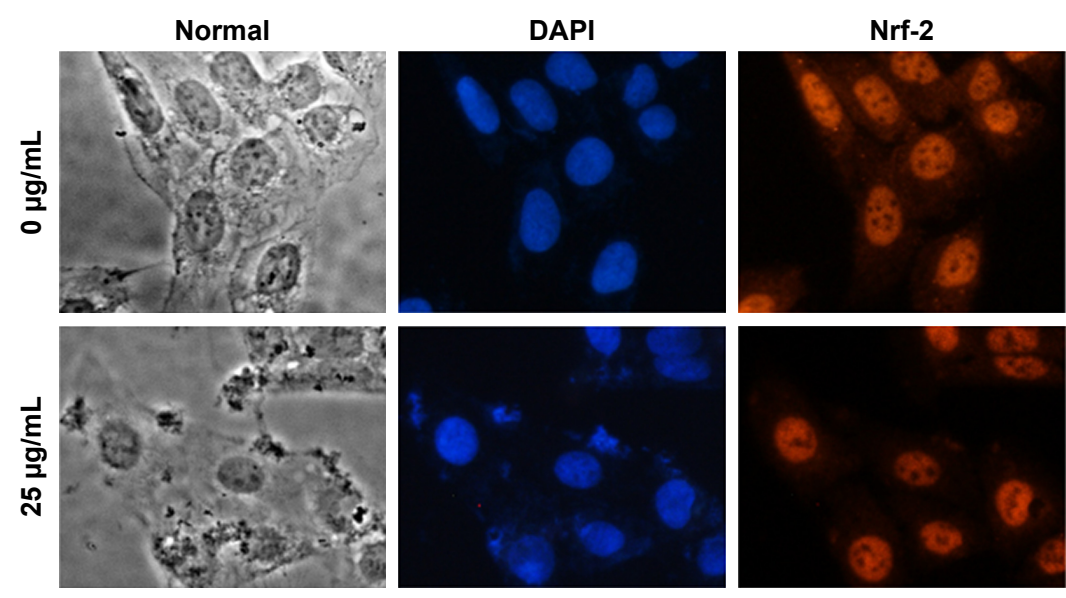

$\mathrm{K}_{7} \mathrm{M}_{2}$
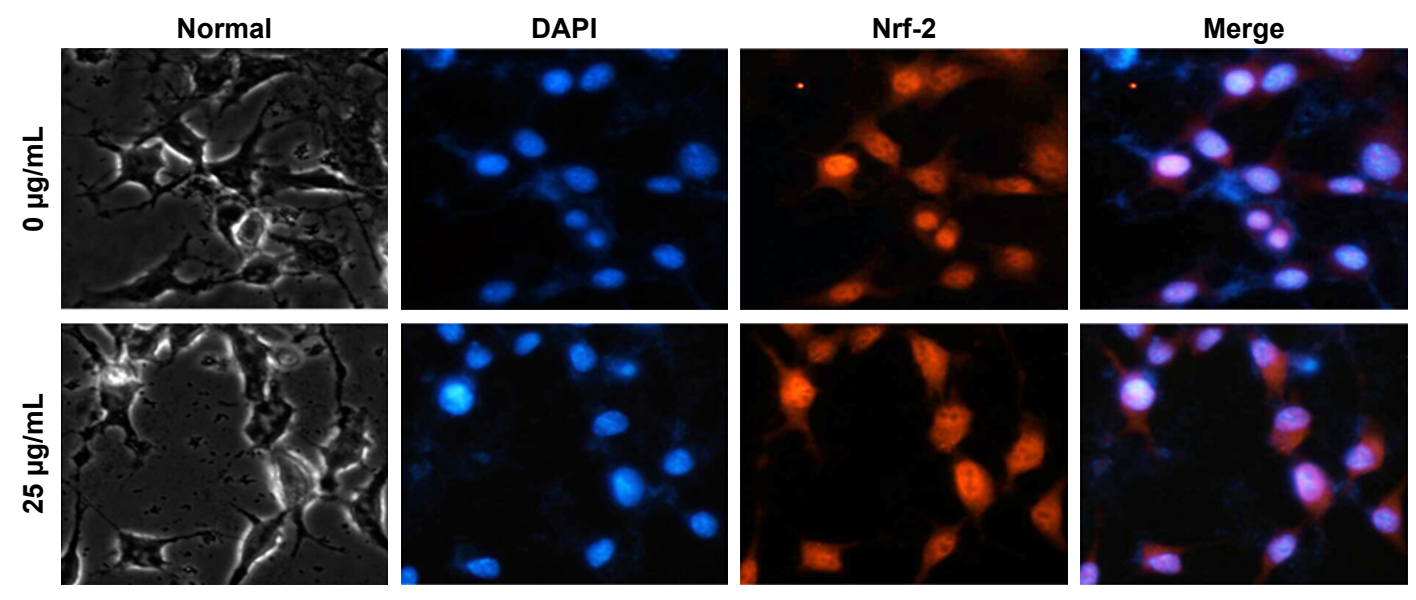

B
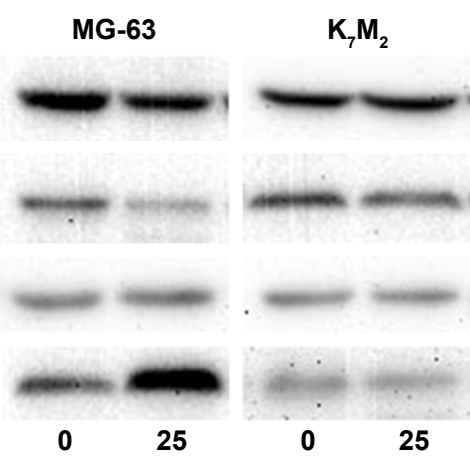

$\beta$-Actin (42 kDa)
Nrf-2 (66 kDa)
Lamin B1 (68 kDa)
Nrf-2 (66 kDa)
$\mu \mathrm{g} / \mathrm{mL}$

\section{Cytoplasm}

Nucleus

Figure 5 (Continued) 


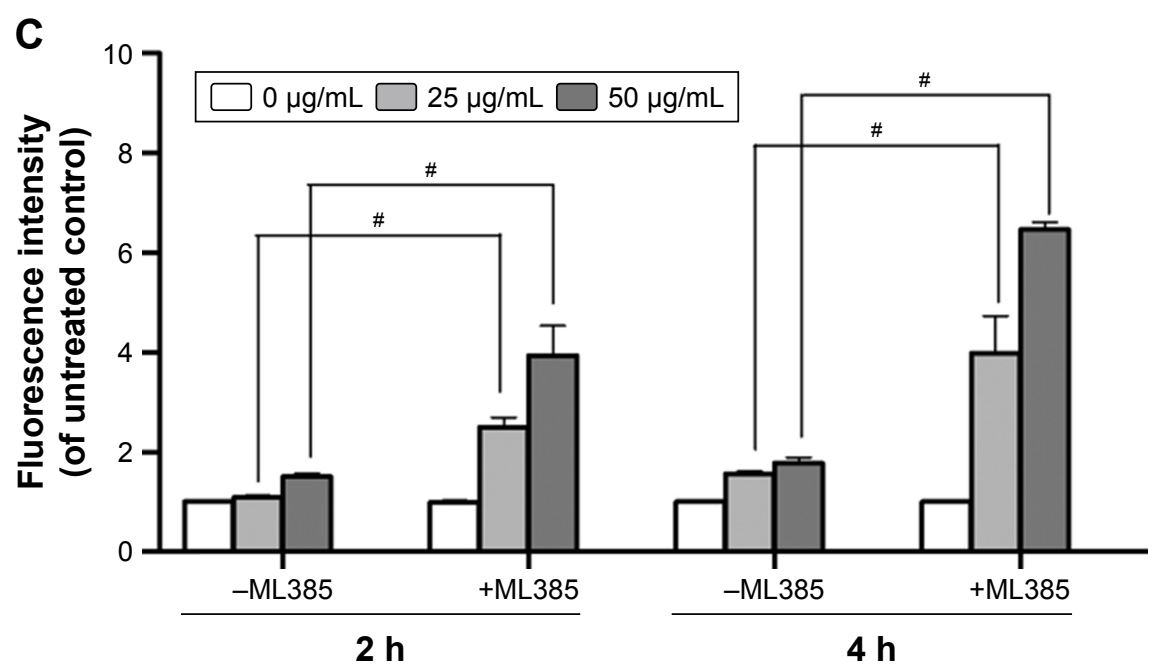

Figure 5 GO induces Nrf-2 transport from the cytoplasm to the nucleus in MG-63 cells.

Notes: (A) MG-63 and $\mathrm{K}_{7} \mathrm{M}_{2}$ cells were treated with or without GO $(25 \mu \mathrm{g} / \mathrm{mL})$ for $2 \mathrm{~h}$. Nrf-2 primary antibody and a rabbit lgG-CY3 secondary antibody were added for immunofluorescence assay $(\times 40)$. (B) Cytoplasmic and nuclear Nrf-2 were determined by Western blot analysis with reference to $\beta$-actin and lamin BI. MG-63 and $K_{7} M_{2}$ cells were stimulated with or without GO $(25 \mu \mathrm{g} / \mathrm{mL})$ for $2 \mathrm{~h}$. Cytoplasmic and nuclear cells were isolated by ER Nuclear and Cytoplasmic Extraction Reagents. (C) Fluorescence analysis of ROS content by DHE. Cells were treated with 0,25 , and $50 \mu \mathrm{g} / \mathrm{mL} \mathrm{GO}$ with or without ML385 ( $2 \mu \mathrm{mol} / \mathrm{L})$ for 2 and 4 h. ${ }^{\# P<0.0 I}$ (compared with GO treatment alone).

Abbreviations: DHE, dihydroethidium; DAPI, 4,6-diamidino-2-phenyl-indole; GO, graphene oxide; ROS, reactive oxygen species.

concentration of $25 \mu \mathrm{g} / \mathrm{mL}, \mathrm{NVA} \%$ markedly increased $(P<0.01)$ compared with VA\% $(P>0.05)$, indicating that the apoptosis event occurred in $\mathrm{K}_{7} \mathrm{M}_{2}$ cells on GO treatment.

To address the molecular basis of GO-induced apoptosis in $\mathrm{K}_{7} \mathrm{M}_{2}$ cells, we determined the apoptosis-related protein expression by Western blot assay (Figure 6B). GO inhibited $\mathrm{Bcl}-2$ protein expression levels, and the reduction was dose and time dependent. In addition, caspase- 3 significantly increased under treatment with GO at the concentrations of 25 and $50 \mu \mathrm{g} / \mathrm{mL}$ for 2,4 , and $8 \mathrm{~h}$. Besides, cleaved-caspase- 3 was also activated after treatment with 25 and $50 \mu \mathrm{g} / \mathrm{mL}$ GO for $8 \mathrm{~h}$. Overall, the results showed that the apoptosis induced by GO was related to the caspase-dependent signal pathway.

\section{GO stimulates autophagy in MG-63 cancer cells}

To gain insight into the mechanism of GO-enhanced growth inhibition of MG-63 cells, we determined the intracellular autophagy level by fluorescence microscopy and Western blot analysis. As shown in Figure 7A, 25 and $50 \mu \mathrm{g} / \mathrm{mL}$ GO induced the formation of autophagic cytoplasmic vesicles in MG-63 cells (autophagosomes). However, significant vesicle formation was not detected in $\mathrm{K}_{7} \mathrm{M}_{2}$ cells, suggesting the occurrence of a state of increased intracellular autophagy in MG-63 cells and not in $\mathrm{K}_{7} \mathrm{M}_{2}$ cells. Moreover, in the presence of 25 and $50 \mu \mathrm{g} / \mathrm{mL} \mathrm{GO}$ for 2,4 , and $8 \mathrm{~h}$, the intensity of LC3-II and autophagy-related ATG5, ATG3, and
ATG7 proteins was markedly promoted, indicating that GO facilitated the autophagy level in MG-63 cells (Figure 7B). Furthermore, the accumulation of LC3-II means increased LC3-II production or decreased LC3-II degradation. To test autophagy flux, the proton pump inhibitor Baf was applied at a saturating concentration $(100 \mathrm{nmol} / \mathrm{L})$, indicating LC3-II accumulation. Compared with $100 \mathrm{nmol} / \mathrm{L}$ Baf treatment alone, the combination of GO $(10 \mu \mathrm{g} / \mathrm{mL})$ and Baf significantly increased LC3-II levels. Thus, these results showed that GO increased autophagosome synthesis, rather than inhibiting LC3-II degradation (Figure 7C).

\section{Discussion}

Several studies have demonstrated the cytotoxic effects of GO on normal, cancer, or bacterial cells. ${ }^{13,18,19}$ However, some data suggested that GO is a safe biologic material that can even enhance the viabilities of certain human cancer cells without any toxicity. ${ }^{20}$ These controversial effects were influenced by various factors, especially blood proteins. Zhou et $\mathrm{al}^{21}$ have demonstrated that the formation of blood protein-graphene corona can effectively reduce GO cytotoxicity. Molecular simulations revealed that aromatic and basic residues, such as arginine, contributed significantly during the adsorption process due to the strong $\pi-\pi$ stacking interactions between their aromatic rings and the graphene $\mathrm{sp}^{2}$-carbons. Furthermore, they studied the decreased cytotoxic effects of protein-coated GO by experimental method and concluded that blood protein weakened the interaction between 

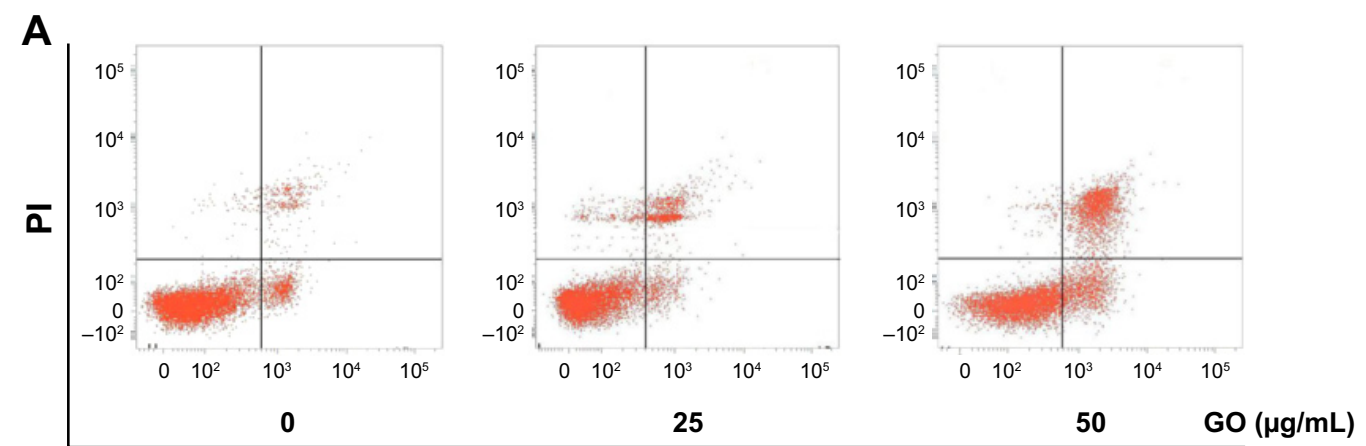

Annexin V-FITC

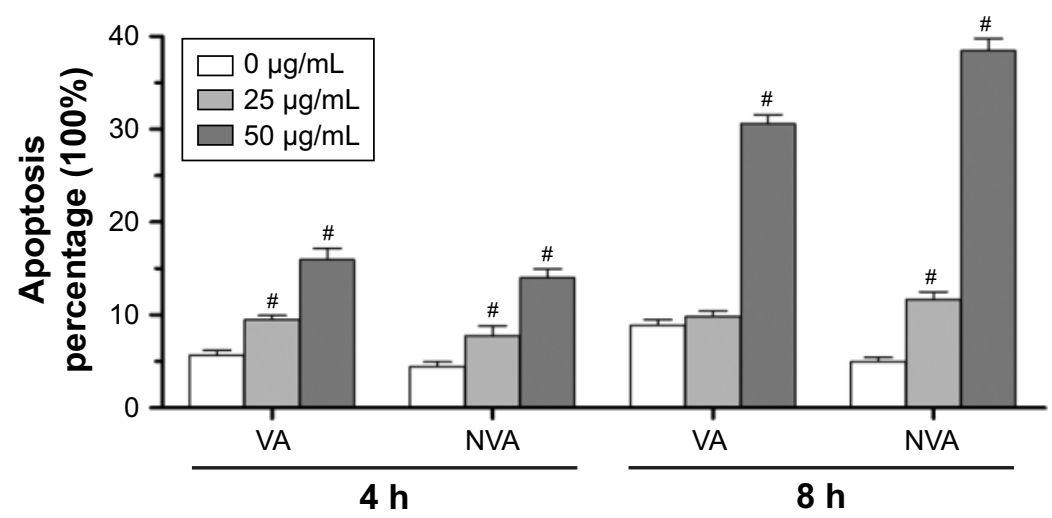

B

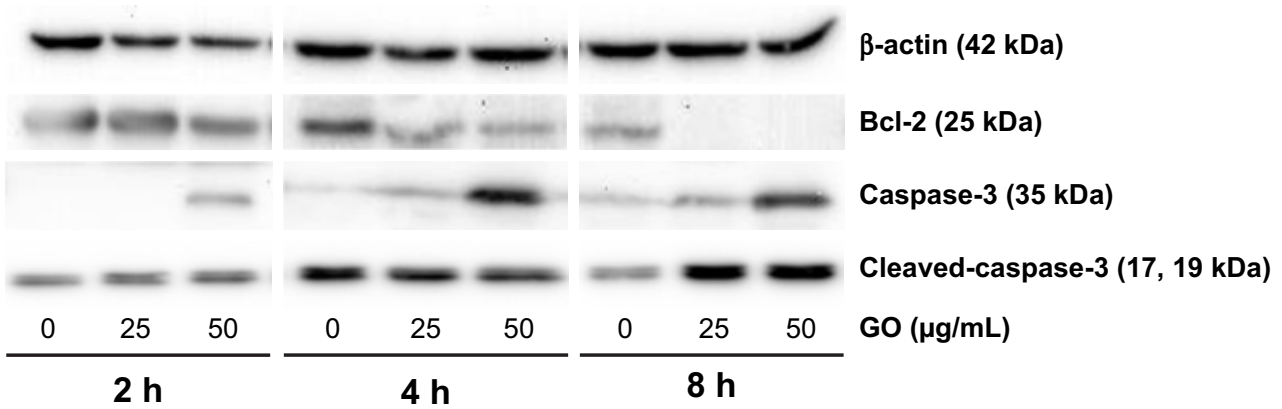

Figure $6 \mathrm{GO}$ induces apoptosis in $\mathrm{K}_{7} \mathrm{M}_{2}$ cancer cells.

Notes: (A) K $\mathrm{K}_{7}$, cells were exposed to 0,25 , and $50 \mu \mathrm{g} / \mathrm{mL}$ GO for 4 and $8 \mathrm{~h}$. Annexin V-FITC Apoptosis Detection Kit was used to determine the percent of early apoptosis (VA\%) and late apoptosis cells (NVA\%). The experiment was repeated three times and one representative experiment is shown, and each value represents the mean \pm SD of three in dependent experiments and compared with untreated control $(\# P<0.0 \mathrm{I})$. (B) GO induces apoptosis in $\mathrm{K}_{7} \mathrm{M}_{2}$ cancer cells, which were treated with 25 and $50 \mu \mathrm{g} / \mathrm{mL}$ GO for 2, 4, and $8 \mathrm{~h}$. Bcl-2, caspase-3, and cleaved-caspase-3 were processed at all concentration points studied.

Abbreviations: GO, graphene oxide; NVA, nonviable apoptosis cell; PI, propidium iodide; VA, viable apoptosis cell.

phospholipids and graphene surface owing to a reduction of the available surface area and the presence of unfavorable steric effect, which significantly reduced graphene penetration and lipid bilayer damage. ${ }^{22,23} \mathrm{In}$ this study, the incubation process of GO without FBS, which excluded the formation of the blood protein-graphene corona and enabled the direct interaction of GO with the cell membrane, finally resulted in toxicity (Figure 1). Compared with the results of other studies, ${ }^{13} \sim 400 \mu \mathrm{g} / \mathrm{mL}$ GO treatment for $24 \mathrm{~h}$ can induce cytotoxic effects on human hepatocellular cancer $\mathrm{HepG}_{2}$ cells. Reduction of doses by $\sim 40 \mu \mathrm{g} / \mathrm{mL}$ GO was observed in our study for inducing the similar effects on the two types of OSA cells, indicating the important function of blood protein in affecting the cytotoxicity and biologic applications of GO.

In addition to its cytotoxic effects, GO was found to induce morphologic changes in MG-63 and $\mathrm{K}_{7} \mathrm{M}_{2}$ cells (Figures 2 and 3). Considerable evidence suggests that GO selectively targets microtubules of the cytoskeleton, thereby enabling its application in cytoskeleton imaging and mitosis tracking in live cells. ${ }^{24}$ The cytoskeleton is a structure that helps the cells to maintain shape and internal organization. Thus, the changes in cell morphology (vimineous and polygonal changes) can be attributed to cytoskeleton damage by GO. In addition, large cytoplasmic vacuoles were detected 

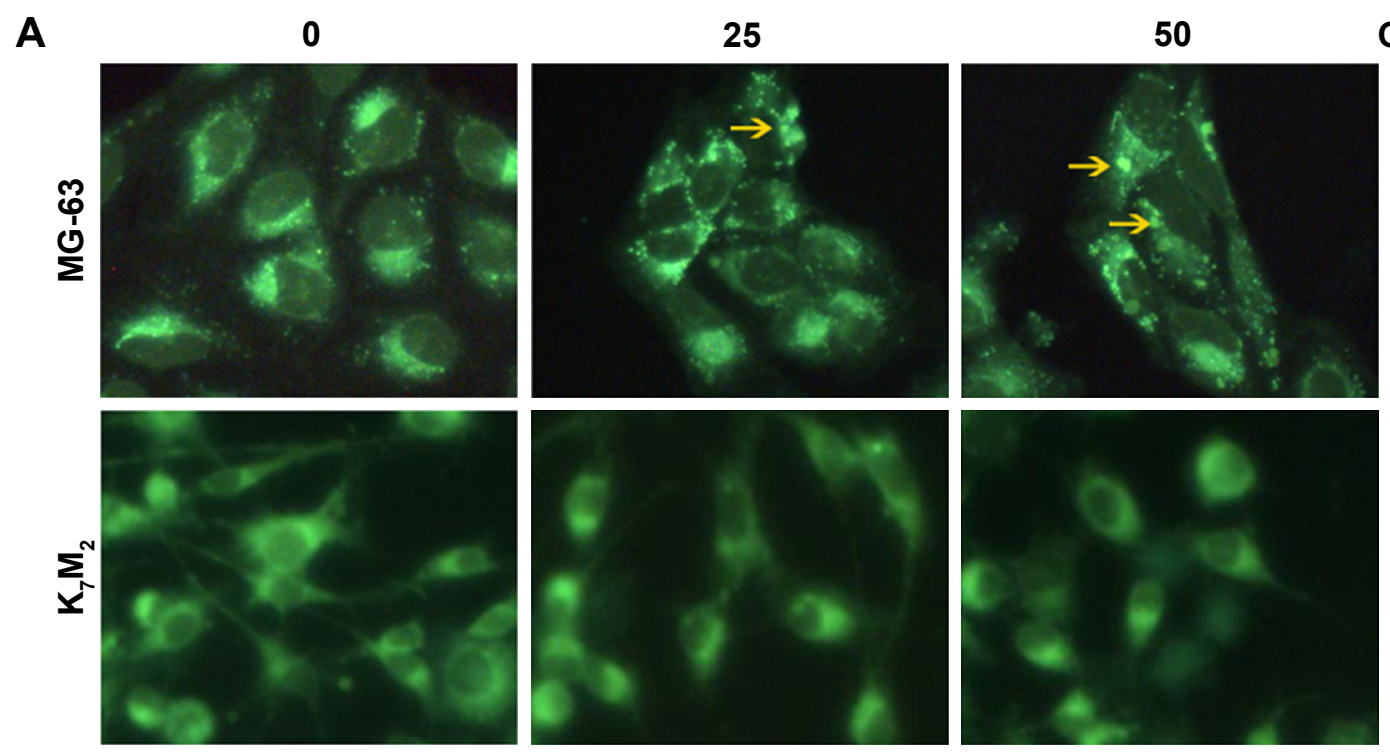

B

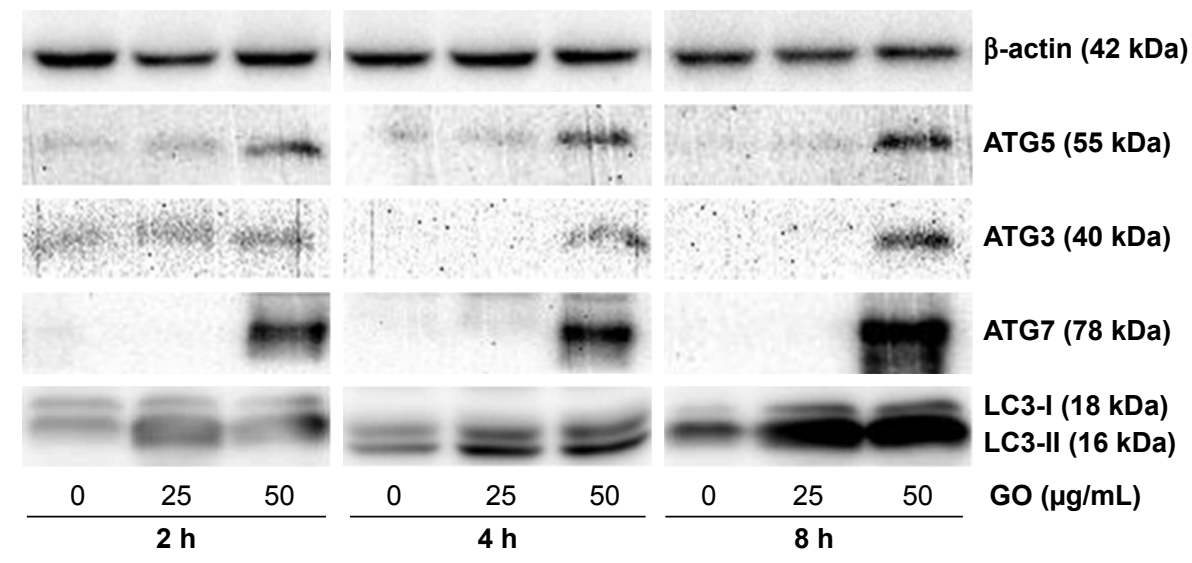

C

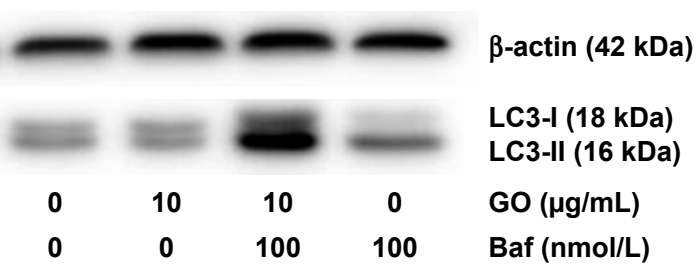

Figure 7 GO stimulates autophagy in MG-63 cancer cells.

Notes: (A) MG-63 and $\mathrm{K}_{7} \mathrm{M}_{2}$ cells were exposed to $0,25,50 \mu \mathrm{g} / \mathrm{mL}$ GO for $2 \mathrm{~h}$, respectively. Autophagy-related punctate structures in the cells were dyed by MDC solution and examined under a fluorescence microscope at $\times 40$ magnification. Yellow arrows: autophagosomes. (B) MG-63 cells were stimulated with 25 and $50 \mu g / \mathrm{mL} G O$ for 2,4 , and $8 \mathrm{~h}$. The ratios of cytosolic LC3-I and lipidated autophagosome-bound LC3-II, ATG5, ATG3, and ATG7 were determined by Western blot. (C) To test the autophagic flux, MG-63 cells were stimulated with $25 \mu \mathrm{g} / \mathrm{mL}$ GO for $8 \mathrm{~h}$ and $100 \mathrm{nmol} / \mathrm{L}$ Baf was added $4 \mathrm{~h}$ before the cells were harvested.

Abbreviations: Baf, bafilomycin Al; GO, graphene oxide; MDC, dansylcadaverine.

in $\mathrm{MG}-63$ and $\mathrm{K}_{7} \mathrm{M}_{2}$ cells after the incubation of $\mathrm{GO}$ at different concentrations ( 25 and $50 \mu \mathrm{g} / \mathrm{mL}$ ). Through the combined experiments and computational molecular simulations in our previous study, strong dispersion interactions between graphene and lipid-tail carbons were suggested to result in depleted lipid density in the cell membrane, ultimately leading to the formation of water-permeable pores. ${ }^{25}$
Although other studies noted that GO can activate autophagous pathways that induce cell death ${ }^{26}$ and that the large vacuoles may be related to the formation of autolysosomes, we still considered that physical damage may be caused by the interaction between $\mathrm{GO}$ and cell membrane owing to the occurrence not only in MG-63 cells but also in $\mathrm{K}_{7} \mathrm{M}_{2}$ cells without autophagy (Figure 7A). 
As an activator of cell apoptosis, ROS can damage the mitochondria by inducing disruption of swelling and decreasing the mitochondrial transmembrane potential and finally activating the apoptosis-related signaling pathway. ${ }^{11,12}$ In $\mathrm{K}_{7} \mathrm{M}_{2}$ cells, $\mathrm{GO}$ easily stimulated ROS production after treatment for only $0.5 \mathrm{~h}$ (Figure 4 ) and effectively induced apoptosis (Figure 6A). Elevated free ROS radicals may cause oxidative damage to mitochondrial DNA, proteins, and lipids with the release of cytochrome $c$; finally, mitochondrial apoptosis pathways are activated. ${ }^{27}$ Subsequently, apoptosis-related proteins, such as Bcl-2 and caspase-3, are affected (Figure 6B), inducing characteristic apoptotic progress (Figure 6A). Cleavage of procaspase- 3 to caspase- 3 is the key step in apoptosis induction. ${ }^{16} \mathrm{GO}$ treatment for $8 \mathrm{~h}$ significantly increased the expression of cleaved-caspase-3 (Figure 6B), finally resulting in characteristic apoptotic progress, such as DNA fragmentation and chromatin condensation. Consistent with a previous study, graphene/ single-walled carbon nanotube hybrids proved to be toxic to two types of OSA cells (HOS and U2OS). It was also found that increased ROS level, decreased mitochondrial membrane potential, and elevated apoptosis were related to its cytotoxic effects. ${ }^{28}$ Regarding the differences between the materials, graphene/single-walled carbon nanotube hybrids have a three-dimensional structure and graphene has a twodimensional structure, and the hybrids are less cytotoxic than graphene. ${ }^{28}$ Another study which combined GO with anti-HER2 antibody trastuzumab confirmed that the complex could simultaneously induce necroptosis in OSA cells by activating oxidative stress and HER2 signaling. ${ }^{29}$ All these studies reveal that GO has great potential in OSA therapy due to its diverse structures and capacity as a carrier.

However, we found that the ROS level was not significantly elevated by GO in MG-63 cells (Figure 4). To further understand the underlying mechanism, we determined the expression and location of the oxidative stress-responding transcription factor, Nrf-2. Under normal or unstressed conditions, Nrf-2 is immobilized in the cytoplasm by a cluster of proteins that degrade it quickly. However, oxidative stress causes the Nrf-2 to translocate to the nucleus, where the factor binds to a DNA promoter and initiates the transcription of antioxidative genes and their proteins, such as superoxide dismutase and heme oxygenase-1 antioxidant enzymes. ${ }^{30}$ Here, on one hand, we found that $\mathrm{GO}$ at the indicated concentrations induced Nrf-2 translocation from the cytoplasm to the nuclei in MG-63 cells, but not in $\mathrm{K}_{7} \mathrm{M}_{2}$ cells (Figure 5A and B), indicating the activation of Nrf-2. On the other hand, Nrf-2 inhibitor, ML385, could significantly increase ROS generation in MG-63 cells. This finding suggests that antioxidant enzymes were probably activated in MG-63 cells, thereby eliminating ROS and maintaining a stable oxidative level. Consistent with our results, silica nanoparticles activated Nrf-2-ERK MAP kinase signaling pathway and exerted toxicity via oxidative stress. ${ }^{30}$

As an evolutionary catabolic process, autophagy is recognized as self-eating or type II-programmed cell death that is crucial for the development and homeostasis of cells. ${ }^{31}$ Under stressful conditions, autophagy allows the degradation of extra proteins and recycling of amino acids for the synthesis of proteins essential for survival. ${ }^{32}$ In our study, GO stimulated autophagy in MG-63 cells through the formation of non-characteristic autophagosomes (Figure 7A) and increase in the expression of autophagy-related proteins (Figure 7B). Notably, type I (cytosolic) LC3 protein could be converted into type II (membrane-bound) LC3 protein, and other autophagy-related ATG5, ATG3, and ATG7 proteins were markedly promoted by GO. In addition, autophagy flux was promoted by $\mathrm{GO}$ with combined treatment of autophagy inhibitor Baf at a saturating concentration, indicating GO could increase autophagosome synthesis, rather than inhibit LC3-II degradation (Figure 7C). During autophagy, ATG-5 is necessary for the formation of the ATG12 conjugation system (ATG12, ATG5, and ATG16) and ATG7 is necessary for the ATG8 lipidation system (ATG8, ATG3, and ATG7). Both systems mediate vesicle expansion and completion. ${ }^{33}$

In conclusion, we found that different mechanisms including oxidative stress, apoptosis, and autophagy were involved in GO-induced anti-OSA effect. The results presented provide the novel mechanisms underlying GO-modulated anticancer effect, which may pave the road for development of nanomaterials for clinical applications in cancer treatment. Further investigation on the improvement of cancer cells' cytotoxic effects and reduction of adverse effects to normal tissue could provide sufficient basis to pursue GO as a novel anticancer agent strategy against human OSA cancer.

\section{Acknowledgments}

This work was supported by the National Natural Science Foundation of China (Grants Nos 81673101 and 81703159), postdoctoral research funding plan in Jiangsu province (1601121C), and the Program of Suzhou Scientific and Technology (SYS201511). This work was also supported by Jiangsu Provincial Key Laboratory of Radiation Medicine and Protection and State Key Laboratory of Radiation Medicine and Protection.

\section{Author contributions}

ZT and LZ contributed equally. ZT, LZ, and HY conceived and designed the research. ZL, JG, BB, JL, and LZ performed 
the experiments and analyzed the data. ZT, LZ, JX, and ZY co-wrote the manuscript. All authors contributed toward data analysis, drafting and revising the paper and agree to be accountable for all aspects of the work. All authors discussed the results and commented on the manuscript.

\section{Disclosure}

The authors report no conflicts of interest in this work.

\section{References}

1. Mirabello L, Troisi RJ, Savage SA. Osteosarcoma incidence and survival rates from 1973 to 2004: data from the Surveillance, Epidemiology, and End Results Program. Cancer. 2009;115(7):1531-1543.

2. Isakoff MS, Bielack SS, Meltzer P, Gorlick R. Osteosarcoma: current treatment and a collaborative pathway to success. J Clin Oncol. 2015; 33(27):3029-3035.

3. Leary SE, Wozniak AW, Billups CA, et al. Survival of pediatric patients after relapsed osteosarcoma: the St. Jude Children's Research Hospital experience. Cancer. 2013;119(14):2645-2653.

4. Gurunathan S, Kim JH. Synthesis, toxicity, biocompatibility, and biomedical applications of graphene and graphene-related materials. Int J Nanomedicine. 2016;11:1927-1945.

5. Peng $\mathrm{S}$, Feng $\mathrm{P}, \mathrm{Wu} \mathrm{P}$, et al. Graphene oxide as an interface phase between polyetheretherketone and hydroxyapatite for tissue engineering scaffolds. Sci Rep. 2017;7:46604.

6. Nejabat M, Charbgoo F, Ramezani M. Graphene as multifunctional delivery platform in cancer therapy. J Biomed Mater Res A. 2017;105(8): 2355-2367.

7. SuX, Chan C, Shi J, et al. A graphene quantum dot@Fe3O4@SiO2 based nanoprobe for drug delivery sensing and dual-modal fluorescence and MRI imaging in cancer cells. Biosens Bioelectron. 2016;92:489-495.

8. Rojas-Andrade MD, Chata G, Rouholiman D, Liu J, Saltikov C, Chen S. Antibacterial mechanisms of graphene-based composite nanomaterials. Nanoscale. 2017;9(3):994-1006.

9. Chae MS, Kim J, Jeong D, et al. Enhancing surface functionality of reduced graphene oxide biosensors by oxygen plasma treatment for Alzheimer's disease diagnosis. Biosens Bioelectron. 2017;92:610-617.

10. Chen YW, Su YL, Hu SH, Chen SY. Functionalized graphene nanocomposites for enhancing photothermal therapy in tumor treatment. Adv Drug Deliv Rev. 2016;105(Pt B):190-204.

11. Wu J, Yang R, Zhang L, Fan Z, Liu S. Cytotoxicity effect of graphene oxide on human MDA-MB-231 cells. Toxicol Mech Methods. 2015; 25(4):312-319.

12. Choi YJ, Kim E, Han J, Kim JH, Gurunathan S. A novel biomoleculemediated reduction of graphene oxide: a multifunctional anti-cancer agent. Molecules. 2016;21(3):375.

13. Loutfy SA, Salaheldin TA, Ramadan MA, Farroh KHY, Abdallah ZF, Youssef T. Synthesis, characterization and cytotoxic evaluation of graphene oxide nanosheets: in vitro liver cancer model. Asian Pac J Cancer Prev. 2017;18(4):955-961.

14. Zhao L, Xu J, Jiao Y, Wang H, Fan S. Novel mechanisms involving chemically modified tetracycline 3 cytotoxicity. Anticancer Drugs. 2014;25(10):1165-1174.

International Journal of Nanomedicine

\section{Publish your work in this journal}

The International Journal of Nanomedicine is an international, peerreviewed journal focusing on the application of nanotechnology in diagnostics, therapeutics, and drug delivery systems throughout the biomedical field. This journal is indexed on PubMed Central, MedLine, CAS, SciSearch ${ }^{\circledR}$, Current Contents ${ }^{\circledR} /$ Clinical Medicine,
15. Mari E, Mardente S, Morgante E, et al. Graphene oxide nanoribbons induce autophagic vacuoles in neuroblastoma cell lines. Int J Mol Sci. 2016;17(12):E1995.

16. Zhao L, Xu J, Yang Y, et al. Inhibitory impacts of chemically modified tetracycline-3 and underlying mechanism in human cervical cancer cells. Anticancer Drugs. 2013;24(8):799-809.

17. Singh A, Venkannagari S, Oh KH, et al. Small molecule inhibitor of NRF2 selectively intervenes therapeutic resistance in KEAP1-deficient NSCLC tumors. Acs Chem Biol. 2016;11(11):3214-3225.

18. Wang Y, Wu S, Zhao X, Su Z, Du L, Sui A. In vitro toxicity evaluation of graphene oxide on human RPMI 8226 cells. Biomed Mater Eng. 2014;24(6):2007-2013.

19. Ricci R, Leite NCS, da-Silva NS, et al. Graphene oxide nanoribbons as nanomaterial for bone regeneration: effects on cytotoxicity, gene expression and bactericidal effect. Mater Sci Eng C Mater Biol App. 2017;78:341-348.

20. De Marzi L, Ottaviano L, Perrozzi F, et al. Flake size-dependent cyto and genotoxic evaluation of graphene oxide on in vitro A549, $\mathrm{CaCo} 2$ and vero cell lines. J Biol Regul Homeost Agents. 2014;28(2):281-289.

21. Gu Z, Yang Z, Wang L, Zhou H, Jimenez-Cruz CA, Zhou R. The role of basic residues in the adsorption of blood proteins onto the graphene surface. Sci Rep. 2015;5:10873.

22. Chong Y, Ge C, Yang Z, et al. Reduced cytotoxicity of graphene nanosheets mediated by blood-protein coating. Acs Nano. 2015;9(6): 5713-5724.

23. Duan G, Kang SG, Tian X, et al. Protein corona mitigates the cytotoxicity of graphene oxide by reducing its physical interaction with cell membrane. Nanoscale. 2015;7(37):15214-15224.

24. Li QR, Jiao JB, Li LL, et al. Graphene oxide-enhanced cytoskeleton imaging and mitosis tracking. Chem Commun (Camb). 2017;53(23): 3373-3376.

25. Duan G, Zhang Y, Luan B, et al. Graphene-induced pore formation on cell membranes. Sci Rep. 2017;7:42767.

26. Wan B, Wang ZX, Lv QY, et al. Single-walled carbon nanotubes and graphene oxides induce autophagosome accumulation and lysosome impairment in primarily cultured murine peritoneal macrophages. Toxicol Lett. 2013;221(2):118-127.

27. Li P, Nijhawan D, Wang X. Mitochondrial activation of apoptosis. Cell. 2004;116(2 Suppl):S57-S61.

28. Yan X, Yang W, Shao Z, Yang S, Liu X. Triggering of apoptosis in osteosarcoma cells by graphene/single-walled carbon nanotube hybrids via the ROS-mediated mitochondrial pathway. J Biomed Mater Res A. 2016;105(2):443-453.

29. Li L, Luo C, Song Z, et al. Association of anti-HER2 antibody with graphene oxide for curative treatment of osteosarcoma. Nanomedicine. 2018;14(2):581-593.

30. Eom HJ, Choi J. Oxidative stress of silica nanoparticles in human bronchial epithelial cell, Beas-2B. Toxicol In Vitro. 2009;23(7): 1326-1332.

31. Rautou PE, Mansouri A, Lebrec D, Durand F, Valla D, Moreau R. Autophagy in liver diseases. J Hepatol. 2010;53(6):1123-1134.

32. Klionsky DJ, Emr SD. Autophagy as a regulated pathway of cellular degradation. Science. 2000;290(5497):1717-1721.

33. Kondo Y, Kondo S. Autophagy and cancer therapy. Autophagy. 2006; 2(2):85-90. 